\title{
PPV susceptibility of commonly used peach rootstock-scion combinations
}

\author{
J. ÁDÁM ${ }^{1}$, Á. BORSOS ${ }^{1}$, I. BALLA², A. ITTZÉS ${ }^{3}$, L. PALKOVICS ${ }^{1}$
}

\begin{abstract}
${ }^{1}$ Department of Plant Pathology, Corvinus University of Budapest, 44. Ménesi Road, H-1118 Budapest, Hungary; ${ }^{2}$ Fruitculture Research Institute, National Agricultural Research and Innovation Centre, 2. Park Street, H-1223 Budapest, Hungary; ${ }^{3}$ Department of Biometrics and Agricultural Informatics, Corvinus University of Budapest, 29-43. Villányi Street, H-1118, Budapest, Hungary
\end{abstract}

Received April 9, 2015; revised April 29, 2015; accepted October 23, 2015

\begin{abstract}
Summary. - Sharka disease is one of the most devastating plant epidemics of Prunus species, caused by plum pox virus (PPV). The viral infection affects the fruits by weight-loss and degradation of quality properties. Breeding of resistant rootstocks and cultivars is one of the most effective disease control methods. PPV determines the peach production all over the world. On the world's fruit production list peach is in the sixth, in the Mediterranean region in the fourth place. In this study new data were shown about PPV susceptibility of commonly used rootstock-scion combinations from Hungary. Reverse transcription PCR (RT-PCR) analysis was conducted on the samples from a commercial orchard; the results were evaluated by chi-square test and binary logistic regression. Four rootstock ('GF677', 'PeMa', 'Cadaman' and almond seedlings) and three scion cultivars (Prunus persicae 'Michelini', 'Babygold 6' and 'Cresthaven') were included in this experiment. The rootstocks did not show any significant differences in regard to the resistance of the virus infection (40-50\%), but in case of scions, strong significant relations were observed. In case of the combinations there were results in both directions; tolerant and susceptible combinations were observed as well.
\end{abstract}

Keywords: Sharka; peach; susceptibility; rootstock scion combination

\section{Introduction}

The first description of plum pox virus (the causative agent of Sharka disease) was reported by Atanasoff in 1932, from $P$. domestica 'Kjüstendil'. PPV is the member of the Potyvirus genus, the family Potyviridae, named after potato virus Y. One third of the plant pathogen viruses belong to this virus family (Ward and Shukla, 1991). Recent studies have demonstrated the occurrence of nine molecularly different PPV strains. Three strains (PPV-M, PPV-D and PPV-Rec) are widely spread (Dallot et al., 1998; Myrta et al., 1998; Glasa et al., 2004), but six have specific geographical locations or infrequent occurrence (PPV-EA, PPV-C, PPV-W, PPV-T, PPV-Man, PPV-CR; Candresse et al., 1994; Nemchinov and

Email: janos.adam@uni-corvinus.hu; phone: +36-1-482-6048. Abbreviations: $\mathrm{PPV}=$ plum pox virus; $\mathrm{RT}-\mathrm{PCR}=$ reverse transcription PCR; RFLP = restriction fragment length polymorphism; $\mathrm{OR}=$ odds ratio
Hadidi, 1996; James et al., 2003; Serçe et al., 2009; Palmisano et al., 2012; Chirkov et al., 2013; Glasa et al., 2013). Sharka disease heavily determines the world's stone fruit production, and causes loss of Euro millions every year (Cambra et al., 2006). PPV infects not only stone fruits but almond (Pribék et al., 2001) and blackthorn (Salamon and Palkovics, 2002), thus a natural wild host species endanger orchards as a reservoir and source of the virus infection by aphid transmission. On susceptible cultivars the $80-100 \%$ of the premature fruits may fall off before harvest. On the world's fruit production list peach is in the sixth, in the Mediterranean in the fourth place (Tóth, 2012). In Hungary, the first description of PPV from peach was reported by Németh in 1963. Screening and breeding for PPV resistance are the most effective long-term strategies against PPV in Hungary because of the GMO free status of the country. Former studies in Hungary have demonstrated that $P$. persicae 'Incrocio Pieri', 'Mayfire' and 'Michelini' have some PPV tolerance (Tóbiás et al., 1992). A five-year-long experiment has been carried out by Salava et al. (2013) in Poland with two rootstock- scion combina- 
Table 1. The examined rootstock-scion combinations

\begin{tabular}{|c|c|c|c|c|}
\hline & & \multicolumn{3}{|c|}{ Scion } \\
\hline & & 'Cresthaven' & 'Babygold 6' & 'Michelini' \\
\hline \multirow{4}{*}{$\begin{array}{l}\frac{y}{0} \\
\frac{0}{0} \\
\frac{0}{0} \\
\stackrel{0}{0}\end{array}$} & 'GF677' & 8 & 8 & 8 \\
\hline & 'Cadaman' & 16 & 12 & 11 \\
\hline & 'Pe Ma' & - & 9 & - \\
\hline & almond seedlings & 10 & - & 9 \\
\hline
\end{tabular}

tions ('Cadaman' x 'Cresthaven' and 'GF677’ x 'Cresthaven') represented also in this study. In the present study new data were shown related to the PPV susceptibility of commonly used rootstock-scion combinations.

\section{Materials and Methods}

The plant material. 91 leaf samples were randomly collected at the beginning of the vegetation from a 15-year-old, 2 square kilometres plantation, located in Sóskút, Hungary. The plantation was naturally infected by PPV, transmitted by aphid vectors. The studied rootstocks were 'Cadaman' (Prunus davidiana x Prunus persica), 'GF677' (Amygdalopersica $x$ hybrida), 'PeMa' (Prunus persica $x$ Amygdalus communis) and almond seedlings (Amygdalus communis). The scions were Prunus persicae 'Michelini', P. persicae 'Babygold 6' and P. persicae 'Cresthaven'.
The combinations of the samples are listed in Table 1. The leaf samples have been stored at $-70^{\circ} \mathrm{C}$ until further studies.

Virus diagnostic and strain identification. After total RNA extraction with Spectrum Plant Total RNA Kit (Sigma-Aldrich), conventional RT-PCR (Maiss et al., 1989) was conducted with M4T reverse orientated primer, located at the 3 ' end (the polyA tail). For cDNA preparation, $1500 \mathrm{ng}$ of total RNA was used. To confirm the presence of PPV, M4 (rev) and S primer (for) Potyviridae-specific primers were used for the PCR, targeting the $3^{\prime} \mathrm{NIb}-5^{\prime} \mathrm{CP}$ region (Chen and Adams, 2001). The 3'P3-6K1-5'CI genomic region was amplified with PP3 (for) and PCI (rev) primers (Glasa et al., 2002). 16 positive samples were further studied by restriction fragment length polymorphism (RFLP) method (Wetzel et al., 1991) for strain identification. The restriction enzymes were EcoRI, DdeI and EcoRV (Glasa et al., 2002; Ádám et al., 2015). Sequence analysis of one isolate (TÉT38) was conducted in the $3^{\prime} \mathrm{P} 3-6 \mathrm{~K} 1-5^{\prime} \mathrm{CI}$ genomic region by the CLC Sequence Viewer 7.0 software. The phylogenetic tree was constructed by UPGMA method, which was accompanied by a bootstrap analysis with 1000 repetitions. A reference isolate from each strain was applied as a standard (Fig. 1).

Statistical analysis. Statistical analysis was carried out with the SPSS 20 (IBM) software package. The chi-square test was used to investigate whether there were any verifiable differences in infection rate among the rootstocks, the scions or their combinations. The crosstabs were made by the infection (as a binary variable) and the other studied parameter (rootstocks, scions and combinations - crosstabs not shown), respectively. Results were considered to be significant when $\mathrm{p}<0.05$, and highly significant when $\mathrm{p}<0.01$. During the investigation of the

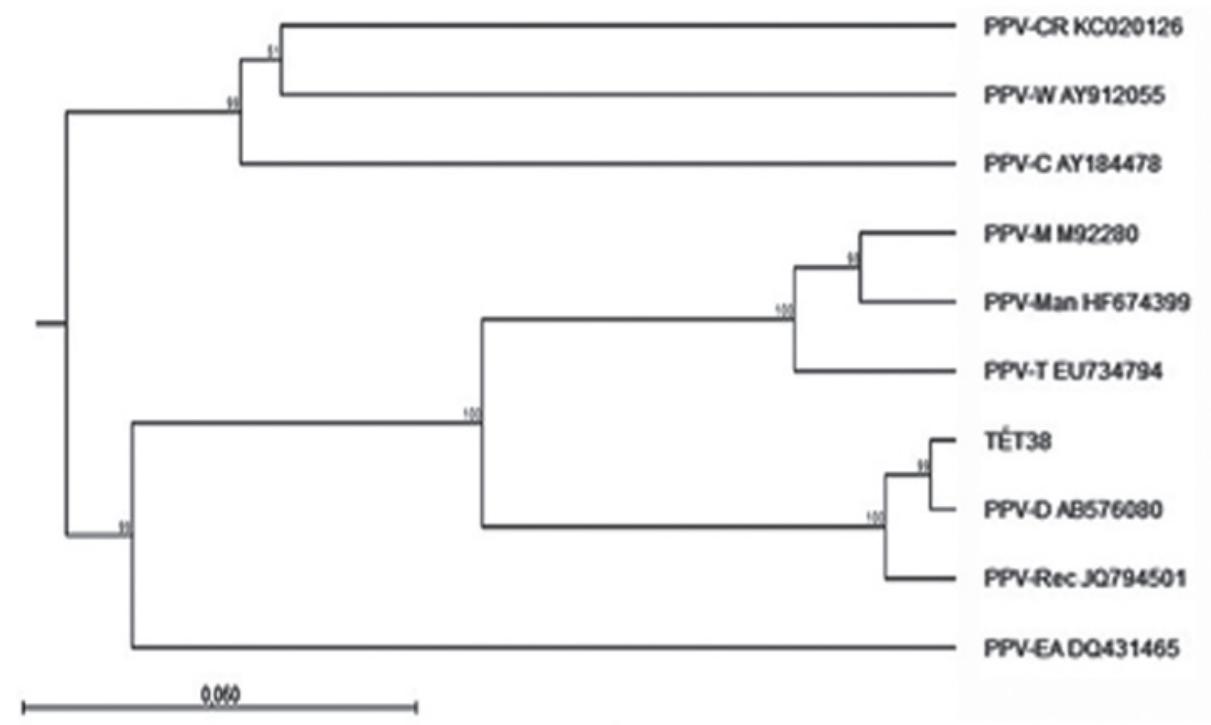

Fig. 1

The phylogenetic tree of the 3'P3-6K1-5'CI genomic regions of different PPV strains and the TÉT38 isolate

The TÉT38 isolate belongs to the Dideron strain. The reference isolates from the NCBI GenBank were the M92280, AB576080, DQ431465, AY184478, JQ794501, AY912055, EU734794, HF674399 and the KC020126 isolate (Palkovics et al., 1993; Fanigliulo et al., 2003; James and Varga, 2005; Glasa et al., 2006, 2013; Serçe et al., 2009; Maejima et al., 2011; Palmisano et al., 2012; Predajňa et al., 2012). 
factors influencing the infection a logistic regression model was used, in which we estimated the probability of occurrence of the studied event. In addition to significance of the logistic regression model, the odds ratio (OR) was determined to examine the differences between the scions and the rootstock-scion combinations. While comparing the scions, the 'Michelini' was chosen as a reference because data shows its PPV tolerant nature (Tóbiás et al., 1992). When comparing the combinations the almond seedling $\mathrm{x}$ 'Michelini' combination was chosen as reference level based on the susceptibility of almond seedlings and the formerly mentioned tolerant nature of 'Michelini'.

\section{Results and Discussion}

Ninety one leaf samples were randomly collected from different rootstock-scion combinations. The studied trees (a) The PPV infection rate of the investigated
rootstock-scion combinations in relation to the rootstocks

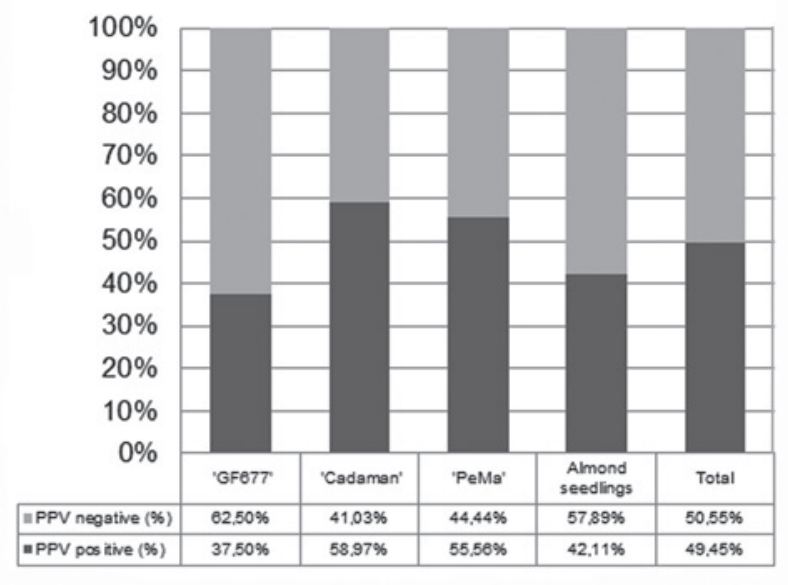

(b)

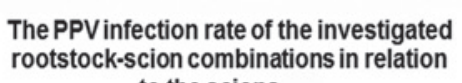

The PPV infection rate of the investigated rootstock-scion combinations in relation to the scions

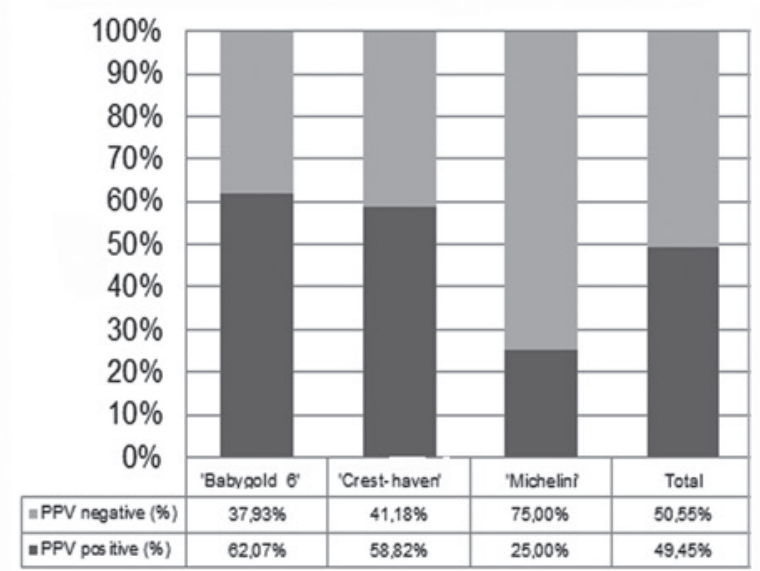

(c)

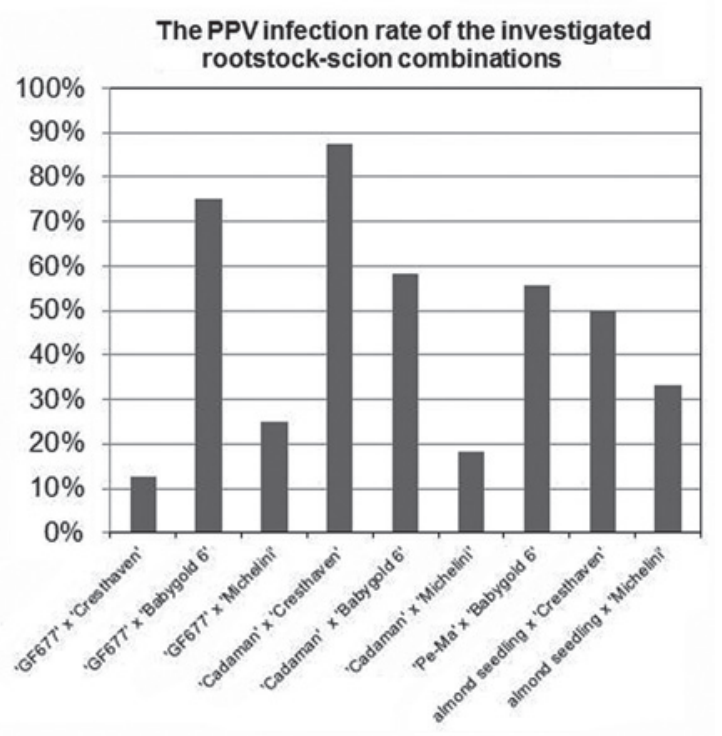

Fig. 2

The PPV infection rate of the rootstocks, scions and their combinations

(a) The PPV infection rate in relation to the rootstocks (\%). On the $\mathrm{x}$ axis are shown the four rootstocks and the total, on the $\mathrm{y}$ axis is marked the infection rate. (b) The PPV infection rate in relation to the scions (\%). On the $\mathrm{x}$ axis are shown the three scions and the total, on the $\mathrm{y}$ axis is marked the infection rate. (c) The PPV infection rate of the rootstock-scion combinations (\%). On the $\mathrm{x}$ axis are shown the rootstock-scion combinations, on the $\mathrm{y}$ axis is marked the infection rate. 
were either symptomless or PPV-infected according to the visual observation. Of 91 samples, 45 were PPV-positive by PCR analysis in both genomic regions. The 15 -year-old plantation shows $50 \%$ infection rate, therefore half of the plants are considered virus-free. The inoculum source was probably not the infected propagation material, but the surrounding orchards or wild plants around the plantation. The inoculum was transmitted by aphid vectors. According to the results of the RFLP analysis conducted on 16 randomly selected positive samples, ten isolates belong to PPV-M strain, four isolates to PPV-D, and in case of two samples $\mathrm{PPV}-\mathrm{M}+\mathrm{D}$ mixed infections were identified. In spite of the high number of the studied samples, PPV-Rec strain was not identified, however, in the same year (2014) a recombinant isolate was observed from an apricot tree located next to the examined peach trees from the same orchard (data not shown). Similarly to the latest data of Šubr et al. (2015), our observation proves the natural host preference of the different PPV strains. A PPV-D isolate (TÉT38) was chosen for sequence analysis, because this strain is less frequent on peach than PPV-M. The nucleotide sequence of the 3'P3-6K1-5'CI genomic region was determined, and the phylogenetic analysis (Fig. 1) confirmed the results of the RFLP. In the statistical analysis of the first case, the two variables were the rootstocks and the infection. The observed significance level in the chi-square test was $p=0.43$, therefore, there were no significant differences between the PPV tolerance of the rootstocks. The rootstock 'GF677' showed a $37.5 \%$ infection rate, which was a lower value than observed in the other cultivars. Despite the expectations the almond seedlings showed lower infection rate than the 'Cadaman' and the 'PeMa' rootstocks, but these results were not statistically significant (Fig. 2a). If the two variables were the scions and the infection, the significance level of the chi-square test was $p=0.008$. In this case the cultivar 'Michelini' had significantly lower probability to get infected than the other scions in this study. In the logistic regression model 'Michelini' was the reference. According to our results, 'Babygold 6' and the 'Cresthaven' had significantly higher odds to get infected than 'Michelini' OR $=4.909$, and 4.286). There was no significant difference between 'Babygold 6 ' and 'Cresthaven' (Fig. 2b). In the third case, the two variables were the rootstock-scion combinations and the infection. The significance level of the chi-square test was $\mathrm{p}=0.004$. The 'Cadaman' x 'Michelini', 'GF677' x 'Cresthaven' and the 'GF677' x 'Michelini' combinations had lower chance to get infected than the other combinations, but, on the other hand, the 'Cadaman' $\mathrm{x}$ 'Cresthaven' combination had higher risk to get infected by PPV. In the logistic regression model the almond seedlings $\mathrm{x}$ 'Michelini' combination was the reference because of the previously described reasons. The OR $<1$ in case of combinations 'GF667' $x$ 'Cresthaven', 'GF677' $\mathrm{x}$ 'Michelini' and 'Cadaman' $\mathrm{x}$ 'Michelini' showed higher
PPV tolerance, but the results were not significant. For the combination 'Cadaman' $\mathrm{x}$ 'Cresthaven', the OR shows the opposite result $(\mathrm{OR}=13,000)$, this combination had significantly higher odds to get infected compared to the reference (Fig. 2c). Based on the results of this experiment there was no evidence of PPV resistance in the studied rootstocks, scions or in their combinations, but some statistically significant results were observed in both directions (susceptibility and tolerance). Since the rootstock 'Cadaman' has a Prunus davidiana parent, its PPV resistant or tolerant feature was expected. According to our results, out of combinations containing this rootstock, only the 'Cadaman' $\mathrm{x}$ 'Michelini' showed a tolerant feature. The rootstock 'GF677' has been reported to be resistant to PPV-D strain according to Rubio et al. (2005), but the interaction with the scion is not clear, since two PPV-D isolates were identified from the 'GF677' $x$ 'Babygold 6' combination. The PPV susceptibility of 'Babygold 6' cultivar was confirmed by our results. Further studies are required to understand the nature of rootstock-scion interactions, and separate rootstock and scion investigations should follow this experiment to define the conclusions and confirm the statistical results. In addition, the study of the strain variability in the different combinations shall be interesting in the future. This work revealed some practical information and experience for farmers and producers, but further detailed studies of more combinations are required in this topic, since many more cultivars and combinations are in production.

Acknowledgement. This work was supported by the TÉT_10-12011-0673 project. The authors thank Dr. Géza Nagy and the Sóskút Fruct Ltd. for the plant material.

\section{References}

Ádám J, Palkovics L, Tóbiás I, Almási A (2015): Presence of sharka disease in the North-Hungarian countries. Acta Hortic. 1063, 55-60. http://dx.doi.org/10.17660/ ActaHortic.2015.1063.6

Atanasoff D (1932): Sarka po slivite, Edna nova virus a bolest. [Plum pox. A new virus disease.] Yearbook University of Sofia, Faculty of Agriculture 11, 49-70.

Cambra M, Boscia D, Myrta A, Palkovics L, Navrátil M, Barba M, Gorris MT, Capote N (2006): Detection and characterization of Plum pox virus: serological methods. EPPO Bulletin 36, 254-261. http://dx.doi.org/10.1111/j.13652338.2006.00983.x

Candresse T, Macquaire G, Lanneau M, Bousalem M, Wetzel T, Quiot-Douine L, Quiot JB, Dunez J (1994): Detection of plum pox potyvirus and analysis of its molecular variability using immunocapture-PCR. EPPO Bulletin 24, 585-594. http://dx.doi.org/10.1111/j.1365-2338.1994. $\underline{\mathrm{tb} 01072 . \mathrm{x}}$ 
Chen J, Adams MJ (2001): A universal PCR primer to detect members of the Potyviridae and its use to examine the taxonomic status of several members of the family. Arch. Virol. 146, 757-766. http://dx.doi.org/10.1007/ $\underline{\text { s007050170144 }}$

Chirkov S, Ivanov P, Sheveleva A (2013): Detection and partial molecular characterization of atypical plum pox virus isolates from naturally infected sour cherry. Arch. Virol. 158, 1383-1387. http://dx.doi.org/10.1007/s00705-013-1630-x

Dallot S, Labonne G, Boeglin M, Quiot-Douine L, Quiot JB, Candresse T (1998): Peculiar plum pox potyvirus D-populations are epidemic in peach trees. Acta Hortic. 472, 355365. http://dx.doi.org/10.17660/ActaHortic.1998.472.41

Fanigliulo A, Comes S, Maiss E, Piazzolla P, Crescenzi A (2003): The complete nucleotide sequence of Plum pox virus isolates from sweet (PPV-SwC) and sour (PPV-SoC) cherry and their taxonomic relationships within the species. Arch. Virol. 148, 2137-2153. http://dx.doi.org/10.1007/s00705003-0175-9

Glasa M, Marie-Jeanne V, Moury B, Kúdela O, Quiot JB (2002): Molecular variability of the P3-6K1 genomic region among geographically and biologically distinct isolates of Plum pox virus. Arch. Virol. 147, 563-575. http://dx.doi. org/10.1007/s007050200006

Glasa M, Palkovics L, Komínek P, Labonne G, Pittnerová S, Kúdela O, Candresse T, Šubr Z (2004): Geographically and temporally distant natural recombinant isolates of Plum pox virus (PPV) are genetically very similar and form a unique PPV subgroup. J. Gen. Virol. 85, 2671-2681. http://dx.doi. org/10.1099/vir.0.80206-0

Glasa M, Prikhodko Y, Predajňa L, Nagyová A, Shneyder Y, Zhivaeva T, Šubr Z, Cambra M, Candresse T (2013): Characterization of sour cherry isolates of Plum pox virus from the Volga Basin in Russia reveals a new cherry strain of the virus. Phytopathol. 103, 972-979. http://dx.doi. org/10.1094/PHYTO-11-12-0285-R

Glasa M, Svanella L, Candresse T (2006): The complete nucleotide sequence of the Plum pox virus El Amar isolate. Arch. Virol. 151, 1679-1682. http://dx.doi.org/10.1007/s00705$\underline{006-0781-4}$

James D, Varga A (2005): Nucleotide sequence analysis of Plum pox virus isolate W3174: evidence of a new strain. Virus Res. 110, 143-150. http://dx.doi.org/10.1016/j. virusres.2005.02.004

James D, Varga A, Thompson D, Hayes S (2003): Detection of a new and unusual isolate of Plum pox virus in plum (Prunus domestica). Plant Dis. 87, 1119-1124. http://dx.doi. org/10.1094/PDIS.2003.87.9.1119

Maejima K, Himeno M, Komatsu K, Takinami Y, Hashimoto M, Takahashi S, Yamaji Y, Oshima K, Namba S (2011): Molecular Epidemiology of Plum pox virus in Japan. Phytopathol. 101, 567-574. http://dx.doi.org/10.1094/ PHYTO-10-10-0280

Maiss E, Timpe U, Brisske A, Jelkmann W, Casper R, Himmler G, Mattanovich D, Katinger HWD (1989): The complete nucleotide sequence of plum pox virus RNA. J. Gen. Virol. 70, 513-524. http://dx.doi.org/10.1099/0022-1317 $\underline{-70-3-513}$
Myrta A, Di Terlizzi B, Boscia D, Caglayan K, Gavriel I, Ghanem G, Varveri C, Savino V (1998): Detection and serotyping of Mediterranean plum pox virus isolates by means of strainspecific monoclonal antibodies. Acta Virol. 42, 251-253.

Nemchinov L, Hadidi A (1996): Characterization of the sour cherry strain of plum pox virus. Phytopathol. 86, 575-580. http:// dx.doi.org/10.1094/Phyto-86-575

Németh M (1963): Field and greenhouse experiments with plum pox virus. Phytopathol. Medit. 2, 162-166.

Palkovics L, Burgyán J, Balázs E (1993): Comparative sequence analysis of four complete primary structures of plum pox virus strains. Virus Genes 7, 339-347. http://dx.doi. org/10.1007/BF01703390

Palmisano F, Boscia D, Minafra A, Myrta A, Candresse T (2012): An atypical Albanian isolate of Plum pox virus could be the progenitor of Marcus strain. In Proc. XII. Int. Conf. Virus and Other Graft Transmissible Diseases of Fruit Crops. Rome, p. 33.

Predajňa L, Nagyova A, Glasa M, Šubr Z (2012): Cloning of the complete infectious cDNA of the plum pox virus strain PPV-Rec. Acta Virol, 56, 129-132. http://dx.doi. org/10.4149/av 2012 $02 \quad 129$

Pribék D, Palkovics L, Gáborjányi R (2001): Molecular characterization of plum pox virus almond isolate. Acta Hortic. 550, 91-95. http://dx.doi.org/10.17660/ ActaHortic.2001.550.10

Rubio M, Martínez-Gómez P, Pinochet J, Dicenta F (2005): Evaluation of resistance to sharka (Plum pox virus) of several Prunus rootstocks. Plant Breeding 124, 67-70. http:// dx.doi.org/10.1111/j.1439-0523.2004.01068.x

Salamon P, Palkovics L (2002): Characterization of Plum pox virus PPV-BT-H isolated from naturally infected blackthorn (Prunus spinosa L.) in Hungary. Eur. J. Plant Pathol. 108, 903-907. http://dx.doi.org/10.1023/A:1021265023657

Salava J, Polak J, Oukropec I (2013): Evaluation of the Prunus Interspecific Progenies for Resistance to Plum Pox Virus. Czech J. Genet. Plant Breed. 49, 65-69.

Serçe ÇU, Candresse T, Svanella-Dumas L, Krizbai L, Gazel M, Kadriye Çağlayan K (2009): Further characterization of a new recombinant group of Plum pox virus isolates, PPV-T, found in orchards in the Ankara province of Turkey. Virus Res. 142, 121-126. http://dx.doi.org/10.1016/j. virusres.2009.01.022

Šubr Z, Kamencayová M, Glasa M (2015): Experimental mixed infection by Plum pox virus strains confirms their natural host preference. Acta Hortic. 1063, 29-32. http://dx.doi. org/10.17660/ActaHortic.2015.1063.2

Tóbiás I, Győző K, Barkaszi I, Szabó Z (1992): A Szilva-himlővírus kimutatása őszibarackból és a fajták érzékenysége. Kertgazdaság 24, 70-77.

Tóth M (2012): Gyümölcsfaj- és fajtaismeret. Budapest. Inkart Kft. Budapest.

Ward CW, Shukla DD (1991): Taxonomy of potyviruses: current problems and some solutions. Intervirology 32, 269-296.

Wetzel T, Candresse T, Ravelonandro M, Dunez J (1991): A polymerase chain reaction assay adapted to plum pox potyvirus detection. J. Virol. Methods 33, 355-365. http:// dx.doi.org/10.1016/0166-0934(91)90035-X 